\title{
Struggling for the Kurdish vote: religion, ethnicity and victimhood in AKP and BDP/HDP rally speeches
}

\author{
loannis N. Grigoriadis (D) and Esra Dilek \\ Department of Political Science \& Public Administration, Bilkent University, Ankara, Turkey
}

Talking about the Kurdish vote in Turkey normally recalls the pro-Kurdish minority parties. A large number - if not the majority - of Kurdish voters have, however, voted for mainstream Turkish conservative political parties. ${ }^{1}$ There is a constant competition for the Kurdish vote, which has been strongly influenced by the politics of the Kurdish question. National identity debates in Turkey have entered a process of transformation since the democratization reforms from 2002 under the Adalet ve Kalkınma Partisi (Justice and Development Party - AKP) rule. This democratization wave inevitably had a positive effect on one of the most oppressed social groups in Turkey, its Kurdish minority. Following significant constitutional and legislative steps between 2002 and 2007, the 'Kurdish opening' (Kürt açılımı) in 2009, the National Unity and Fraternity Project (Milli Birlik ve Kardeșlik Projesi) in 2010 and, finally, the resolution process (çözüm süreci) that was initiated officially in January 2013 were all major steps in challenging the traditional securitized approach to the Kurdish issue. In all regards, these processes of transformation challenged the traditional secular state approach that had built itself on repressing Islamic and Kurdish identities for decades. It also changed the parameters of electoral competition between the AKP and the parties representing Turkey's Kurdish minority, notably the Peace and Democracy Party (Barış ve Demokrasi Partisi - BDP) and the Peoples' Democratic Party (Halkların Demokratik Partisi - HDP).

This study explores the June 2011 and June 2015 elections and seeks to explain how the two parties that have dominated the Kurdish vote, the AKP and the pro-Kurdish BDP/ HDP, appealed to voters. The June 2011 and June 2015 elections were crucial, as they took place under the turbulent conditions of AKP's Kurdish policies oscillating between a break with the traditional securitized approach to the Kurdish issue and the progressive approach framing the issue in terms of democratization and human rights. Religion, ethnicity and citizenship are variously employed in the party rhetoric which is also characterized by an emphasis on victimhood. This study seeks to answer the questions of how religion, ethnicity and citizenship interplayed in the political campaign of the parties and how the parties put their claim of victimhood to appeal to their voters. For the purpose of answering these questions, rally speeches were selected from the eastern and south-eastern provinces in Turkey where the two parties control the clear majority of votes and where ethnic Kurds comprise most of the population. 


\section{National identity transformation in Turkey: religion, ethnicity and victimhood}

Understanding the transformation of national identity in Turkey since 2002 requires a brief overview of republican Turkish nation-building. The Republic of Turkey was established in 1923 after the dissolution of the Ottoman Empire and evolved into a secularist unitary nation-state, thanks to the reform programme of its founder Kemal Ataturk. Ataturk promoted a strict programme of top-down modernization, aiming to bring religion under strict state control and eliminate religion from the public sphere. With regards to nationalism and identity, the modernization programme sought to promote a single Turkish ethno-political identity based on a civic understanding of citizenship. ${ }^{2}$ However, the topdown construction of a single identity meant that Turkishness prevailed over the diverse ethnic, religious and cultural legacy emanating from the Ottoman past and, accordingly, it meant the suppression of all minority groups, in particular of the largest minority group, the Kurds. Both secularism and Turkish national identity came under pressure with the advent of multi-party politics and Turkey's steps towards democratic consolidation. The emerging left-wing social movements, political Islam and Kurdish nationalism challenged the Kemalist modernization project.

Under these circumstances it was inevitable that identity politics would gain influence: the emergence of Islamist, Alevi and the Kurdish nationalist movements reflected that trend and forced the reconsideration of official Kemalist ideology. The decision of the 1980-1983 Evren military regime to embrace the Turkish-Islamic Synthesis (TIS) ${ }^{3}$ and raise it to quasi-official state ideology ${ }^{4}$ was a radical break from the Kemalist tradition. Yet it was seen as an essential step in order to deter the rise of socialist and Kurdish nationalist movements. As the Kurdistan Workers' Party (PKK) endorsed a left-wing anti-imperialist discourse that endorsed secessionism, employed terrorism and guerrilla warfare to achieve its means, the Kurdish issue was fully securitized. The official position framed the Kurdish question in terms of separatism, terrorism, economic and cultural backwardness, and foreign incitement, ${ }^{5}$ and not on the basis of identity or human rights recognition. Sunni Islam was presented as the essential bond between all citizens of Turkey. Nonetheless, official instrumentalization of Sunni Islam had a spill-over effect, with respect to the reinforcement of political Islam, when Turkey returned to a multi-party system.

Despite the persecution of Islamist political movements in the 1990s, the AKP was able to form a single-party government following the 2002 parliamentary elections. The AKP reshaped national identity politics in Turkey by challenging the main pillars of identity construction under the Kemalist establishment. By projecting itself as a conservative democratic party, the AKP first distanced itself from the tradition of Islamic political parties of the National Outlook in Turkey. At the same time, the AKP sought to promote a version of conservatism that was based on 'the synthesis between liberal desires for reform and conservative (religious) cultural sensitivities'. ${ }^{6}$ The AKP criticized the assertive secularist character of the Turkish state not from the perspective of Islamism but from a liberal perspective. ${ }^{7}$ The critique of the traditional state approach to identity encompassed the Kurdish issue, too. The AKP sought to distance itself from the harsh official line approaching the Kurdish problem strictly in security terms and framing the issue as terror and separatism. While during its first term in power, the AKP chose to remain silent on the Kurdish issue, the party's second term was marked by steps that prepared the ground for major 
policy initiatives. The first signal was given by Recep Tayyip Erdoğan in 2005 when at a speech in Diyarbakır he declared that 'the Kurdish problem is my problem'. ${ }^{8}$ This was the first time a prime minister recognized past wrongdoings of the state towards its Kurdish citizens and it marked a turning point in terms of the official approach to the Kurdish issue and Kurdish identity.

Based on this background, the AKP initially promoted a version of 'Türkiyeli' understanding of civic identity based on 'citizenship of Turkey' rather than being 'Turk'. Türkiyelilik can be regarded as a concept of civic citizenship embracing all people born within the borders of Turkey regardless of ethnicity and religion. ${ }^{9}$ Erdoğan first used the concept of Türkiyelilik in the initial year of AKP rule, ${ }^{10}$ and later made sporadic references to it by declaring the need to consider a 'supra-identity' (üst kimlik) that would encompass all 'subordinate identities' (alt kimlik) such as ethnic ones ${ }^{11}$ and that would unite people under the notion of 'citizenship of the Turkish Republic'. ${ }^{12}$ Erdoğan has repeatedly distanced his party from any ethnic nationalism ${ }^{13}$ declaring that citizenship of the Republic of Turkey (being 'Türkiyeli', that is, 'from Turkey' and not 'Türk', that is, 'being ethnically Turk') is the overarching identity for all. This was, however, eventually abandoned, and the AKP moved to a discourse on 'Islamic brotherhood' by promoting Sunni Muslim identity as a supra-identity for Turks and Kurds and situating Kurdish identity as more of a folkloric sub-identity. ${ }^{14}$ This discourse became prominent throughout the AKP's effort to promote new policies for solving the Kurdish issue, starting mainly with the policies of 'opening' in 2009.

The Kurdish movement disputed the claims that it harboured anti-Islamic elements and criticized the AKP's Sunni Muslim fraternity discourse on the basis that it promotes the hegemony of Turkish ethnic identity. ${ }^{15}$ Interestingly, at the same time, the discourse on Türkiyelilik was also used by the pro-Kurdish political movement in an adverse manner. The pro-Kurdish political movement sought to challenge the mono-ethnic approach to national identity construction by promoting demands for recognition of Kurdish ethnic and political identity. Like the AKP, the tradition of pro-Kurdish political parties increasingly framed their demands on liberal rights terms. Becoming visible with the electoral success of pro-Kurdish parties since 2007, the Kurdish political movement made clear demands on the recognition of a political status of the Kurds, referring to both the related constitutional changes for the establishment of a truly civic understanding of citizenship and the recognition of the collective and cultural rights of Kurds as a distinct ethnic identity in Turkey. However, a deeper transformation can be discerned in recent years about the notion of Türkiyelilik.

Alongside religion and ethnicity, victimhood (mağduriyet) has been another persistent feature of the politics of Turkey's Kurdish question. All political parties that competed for the Kurdish vote have claimed to be representatives of the oppressed in Turkish society. Mainstream conservative and pro-Kurdish minority parties claimed that they represented the oppressed through competing definitions of victimhood. The first claimed to represent Turkey's 'silent majority', the conservative lower-middle class, labourers and farmers whose Islamic faith was suppressed under the Kemalist modernization project regardless of their ethnicity. ${ }^{16}$ The second claimed to give voice to the millions of Turkish citizens of Kurdish descent whose cultural rights were denied following decades of republican assimilation policies. This became a crucial part of their electoral strategy and a recurrent theme in their political discourse. 


\section{From the 'Kurdish opening' to the 'resolution process': the June 2011 and June 2015 general elections in context}

The AKP launched the Kurdish opening in 2009 as an important step for openly addressing the Kurdish issue in Turkey. The 'Kurdish opening' (Kürt açılımı), later renamed the 'democratic opening' (demokratik açılım), was the first instance of openly challenging the traditional official state policy of non-recognition of the Kurdish problem and approaching the problem beyond the conventional security framework. The reform steps involved the establishment of Kurdish studies centres at universities, the renaming of Kurdish villages with their original names, the use of languages other than Turkish in courts and the establishment of a public Kurdish-language television channel (TRT Şeş). However, prosecutions of Kurdish political activists continued on terrorism charges, and in December 2009, the pro-Kurdish Democratic Society Party (Demokratik Toplum Partisi - DTP) was banned by the Constitutional Court. The 'democratic opening' was suspended, and armed conflict resumed, following the nationalist outcry provoked by the triumphant reception of thirteen retired PKK members who were allowed to return to Turkey in accordance with an agreement between the Turkish government and the PKK.

In light of the above, the June 2011 elections took place under intense political circumstances. The elections were also affected by the polarized political climate of the September 2010 referendum on constitutional amendments. The fierce opposition of the CHP (Cumhuriyet Halk Partisi - Republican People's Party) and the MHP (Milliyetçi Hareket Partisi - Nationalist Action Party) and the boycott by the $\mathrm{BDP}^{17}$ to constitutional amendments were mainly directed towards concern with increasing authoritarian tendencies of the AKP and increasing conservatism. Against this background, the 2011 elections resulted in the victory of the AKP which gained almost 50 per cent of the votes and secured a singleparty majority in the parliament.

Following the AKP victory in the June 2011 elections, it was uncertain whether the 'democratic opening' would continue. In March 2012, the signs for the start of a new policy for the solution of the Kurdish issue were given by the then President Abdullah Gül. The new process was launched in early 2013 under the name 'resolution process' (çözüm süreci) and marked unprecedented steps regarding the Kurdish issue on many grounds. One unprecedented move was the inclusion of the imprisoned historic leader of the PKK Abdullah Öcalan in the talks and relatedly, the formation of a group by the pro-Kurdish party deputies as a channel for communication between Öcalan and the PKK administration in the Kandil mountains. Accordingly, the resolution process officially started in January 2013 when a group of HDP members visited Öcalan in his prison in Imralı island. This was followed by the partial demobilization of PKK members and their withdrawal to neighbouring countries in the east and south-east, mainly Iraq and Syria.

Until its final collapse following the June 2015 elections, the 'resolution process' was marked by ups and downs, as both parties expressed their discontent with the process. Unfulfilled expectations were closely related to the way the two sides to the process approached the solution to the Kurdish issue. The AKP and its leadership declared that their primary expectation was the disarmament of the PKK. ${ }^{18}$ On the other hand, the proKurdish side expected that democratization steps involving recognition of Kurdish identity and the granting of full cultural and collective rights would be achieved alongside the PKK disarmament. $^{19}$ 
The start of the election campaign ahead of the June 2015 elections contributed to the escalation of rhetoric between the two sides. In March 2015, after an earlier meeting between AKP and pro-Kurdish party representatives, Erdoğan made statements on the 'freezing' of the resolution process and eventually on the non-existence of a Kurdish problem as a whole. ${ }^{20}$ As a response, the pro-Kurdish side made increasingly harsh statements accusing the AKP side of violating the agreed principles.

\section{Election rallies as a tool for campaign communication}

The reasons for analysing election rally speeches are many: first, election rallies are a crucial part of political campaigning in election periods. ${ }^{21}$ Rallies provide the platform for communicating election promises directly to the electorate in a specific area. Second, election rally speeches provide the material needed to understand how party leaders frame their respective voter target groups. Analysing election rally speeches in Kurdishpopulated areas gives valuable information on what the two political sides to the peace talks wanted to communicate to the populations mostly affected by the conflict. A third point is that rally speeches can be seen as a combination of prepared and spontaneous material. Therefore, election rally speeches can be regarded as providing valuable information on the political approach of actors (mainly party leaders) to the Kurdish issue and the resolution process beyond the official election manifestos. Election speeches are useful in understanding which of the themes/areas that were included in the election manifestos would be prioritized for a specific audience. It is expected that matters related to the Kurdish issue and its resolution would be central in speeches addressing a Kurdishmajority audience. Finally, rally speeches highlight the national ideology that each party aspires to communicate to its voters. Especially in a region torn by ethnic conflict, the way political leaders framed the Kurdish question through religion, ethnicity and victimhood is critical in that respect.

Building on these considerations, four rallies for each election period for each party were selected. The selection of the rally speeches was made based on whether the Kurdish issue was central to the speech. A secondary selection criterion was the availability of the data for the BDP rallies for the 2011 elections. Speech data for these elections were scarce and only sporadically recorded, since there was no consolidated political party on the pro-Kurdish front. The rallies were selected from the eastern and south-eastern provinces $^{22}$ of Turkey where the Kurdish population is dense. The AKP rally speeches for the 2011 election were all retrieved from the transcripts of speeches posted on the official website. For the 2015 elections, some of the speeches were retrieved from online video recordings of the speeches. The speeches by independent candidates aligned with the BDP were retrieved from online video recordings and from newspapers that provided transcribed parts of the speeches.

\section{AKP rally speeches in the June 2011 general elections}

In the 2011 elections, the AKP's main strategy was to consolidate its appeal to Turkish and Kurdish conservative voters. Considering this, it adopted an increasingly religious discourse among Kurdish voters to ameliorate the negative effects of its otherwise Turkish nationalist discourse. ${ }^{23}$ This was prominent in election rallies held in the 
Kurdish-populated provinces. An overview of the Bingöl, Diyarbakır, Hakkâri and Van rallies, all in major Kurdish-populated cities in eastern and south-eastern Turkey, by Prime Minister Recep Tayyip Erdoğan, ${ }^{24}$ are provided below. These rallies were selected on the basis that they offer the most comprehensive account of how the AKP envisioned the Kurdish issue. ${ }^{25}$

The theme of religious fraternity emerged as the key theme of reference in Erdoğan's rally speeches in four major Kurdish-populated areas of eastern and south-eastern Turkey: Bingöl, Diyarbakır, Hakkâri and Van. In these rallies, references to religion were marked by two trends: the first built on negative campaigning against the HDP and the CHP. This was prominent in Erdoğan's Diyarbakır ${ }^{26}$ speech where the AKP leader referred to the killing of prayer leaders and accused the BDP members of the statement that the religion of Kurds is Zoroastrianism, of the organization of gender-mixed communal prayers and of alternative prayers with the aim of dividing the Kurds and the Turks, and declaring Öcalan a prophet. A recurring statement was that the HDP was applying similar repression tactics against the pious Kurds as those of the CHP of the 1940s. This argument relied on the AKP's accusation of Turkish republican secularism as having oppressed the pious Turkish citizens who found the opportunity to participate in political life only after the AKP came to power in 2002. Erdoğan assaulted the BDP because it exploited the Kurdish issue and collaborated with the CHP by implementing 'civil fascism'. On this ground, he equated the assimilation and repression policies of the CHP period with the oppression by the terrorist group (referring to the PKK) and the BDP. He further established a common history of the oppressed with reference to the oppression of the conservatives in the name of secularism and the oppression of the Kurds in the name of Turkishness by declaring that 'we went through oppression together'.

A similar pattern could be discerned in Erdoğan's Bingöl rally ${ }^{27}$ that took place on 8 June 2011. Erdoğan referred to the Kurdish call to prayer resembling CHP's Turkish call to prayer in the 1940s by stating that 'They ended up being like the CHP in the 1940s, prostatus quo, oppressive and fascist. [...] As the CHP initiated the Turkish call to prayer, so the BDP wants the Kurdish call to prayer.' Also, Erdoğan extensively criticized Öcalan's comments on religion and his self-declaring as a prophet, and his attack on Muslim prayer by saying it was 'theatre'. A repeating theme in creating parallels between the CHP and the BDP was the statement that 'the patent of the Kurdish issue belongs to the CHP and the abuse of it belongs to the BDP'.

The second trend built upon this negative image of the HDP. The argument then followed that pious Turks and Kurds shared a common history of oppression, since the Kurds were not only oppressed in religious terms but also faced decades-long oppression by PKK terrorism in eastern and south-eastern Turkey. Following this argument, statements on religious fraternity were underlined. References to historical personalities such as Ahmed-i Hani, Feqîyê Teyran (Diyarbakır rally) and Melayê Cizîrî (Bingöl rally) were extensive. This was combined with the theme of nationalism and common history. Depicting this trend, Erdoğan's Van and Hakkâri rallies had a less religious tone and focused more on common history. The Van election rally of 20 May 2011 was replete with references to common history in the area and with references to fraternity and shared religion. ${ }^{28}$ Erdoğan stated that 'since we have so many commonalities, why should we depreciate each other's language, colour, and ethnicity?' and widely argued that the AKP has erased assimilation by stating that 'Aren't there Kurdish friends in my cabinet? There are 60 Kurdish 
deputies in my party. So, we have erased assimilation.' Erdoğan also made references to previous bans on Kurdish music, literary work and books, which had been lifted gradually since the AKP had come to power. References were made to a series of symbolic moves made in Van including the naming of public spaces after the names of famous Kurdish historical figures such as Saladin, Ahmed-i Hani, Feqîyê Teyran and Melayê Cizîrî. Similarly, Erdoğan's Hakkâri rally ${ }^{29}$ of 21 May 2011 centred on criticizing social oppression by the PKK and criticizing the BDP's municipal work in Hakkâri. Erdoğan made references to the publication of once forbidden literary works by Ahmed-i Hani and the retrieval of Kurdish names for villages and steps regarding the Kurdish language by declaring that 'there is no more refusal, abnegation assimilation'.

The rally speeches revealed the AKP's effort to promote a bond between Turks and Kurds based on Islamic identity and common history. In all four rallies under consideration, the speeches devoted minor space to the policies of the AKP on the Kurdish issue. There were limited references to accomplishments under the National Unity and Fraternity Project: the abolition of the state of emergency in the eastern and south-eastern provinces, steps regarding the use of the Kurdish language such as broadcasting in Kurdish on state television and arrangements for teaching in Kurdish at private institutions, and wider freedom in terms of cultural practices. There was no reference to possible future developments on resolving the grievances of the Kurds.

\section{BDP/EDÖB rally speeches in the June 2011 elections}

For the 2011 elections, the BDP/EDÖB (Emek, Demokrasi ve Özgürlük Bloku - Labour, Democracy and Freedom Block) rallies were selected mainly on the basis of the availability of data. Due to the fact that the pro-Kurdish front decided to enter the elections through independent candidates and that there was no consolidated political party, data on the election rallies in 2011 is scarce and widely unavailable. A further limitation is that some of the rallies were conducted in Kurdish and were recorded only sporadically. Following these concerns, four election rallies were selected: Bingöl, Diyarbakır, Hakkâri and Kars.

The BDP/EDÖB rallies for the 2011 elections were highly contingent on the independent candidate making the speech. Candidates known as more religiously oriented, such as Altan Tan and Şerafettin Elçi, focused on statements on the conservative and religious orientation of the Kurds and the declaration that the Kurdish political movement is protective not only of the rights of the Muslim Kurds but of all religious minorities such as the Alevis. For example, religion was a central theme in the Bingöl rally of 10 June $20111^{30}$ where Altan Tan based his speech mostly on religious themes. Tan underlined that 'the Kurdish people are Muslims; they are not going to give up either their religious identity or their ethnic identity, or their language'. Tan also noted that no force could fight real Islam in the Middle East. By referring to 'real Islam', Tan implied that Kurds were deeply engaged with their religion. Similarly, in the Diyarbakır rally, the conservative candidate Elçi noted that: 'you are not allowed to attack the religion of the Kurds. The Kurds are the first nation/society to adopt Islam after the Arabs. We know how many years ago our ancestors became Muslims. ${ }^{31}$ Elçi also made a call to pious Kurds (including those supporting Hezbollah) to join their party so as not to be abused because of their religion.

On the other hand, other candidates voiced the main political demands of the Kurdish political movement, including the rights of Kurds to self-determination, a call for the 
political status of the Kurds to be recognized, self-governance and language rights. The Diyarbakır rally of 3 June $2011^{32}$ centred on these four themes. ${ }^{33}$ Several of the BDP/ EDÖB's candidates participated in the rally. In line with the BDP/EDÖB's call for administrative changes in Turkey, the candidates in the Diyarbakır rally made extensive references to the need for the decentralization and self-determination of Kurds. On this, Şerafettin Elçi noted that 'we are asking for self-governance within the framework of legitimacy. The UN International Covenant on Political and Civil Rights confirms the right to self-determination', while Filiz Kocali stated that: 'Turkey should be organized in 25 self-governing regions [...] We will not accept a new constitution where people/communities are not equal.' Similarly, Hamit Geylani underlined that 'the solution for the Kurdish side is selfdetermination, i.e. giving status to the Kurds'. With regards to the issue of language, Elçi also underlined that 'education in our native language is a must to stop assimilation [...] nowhere in the world has education in the native language led to separatism'.

The Kars and Hakkâri rallies were centred on inclusiveness in terms of identity and on the need for political status for the Kurds. In the Kars election rally of 9 June 2011, ${ }^{34}$ Osman Baydemir made references to the multiple identities existing in the region and the need for protecting each of these identities, including Circassian, Alevi and Jafari identities. In the Hakkâri election rally of 7 June $2011{ }^{35}$ the speeches by Selahattin Demirtaş and Hamit Geylani centred on the theme of democratic self-governance and the need for a political status for Kurds. Demirtaş also underlined that the Kurdish people wanted 'honourable peace' that would mean freedom for the Kurdish people and freedom for Öcalan, the imprisoned PKK leader who is the architect of this peace by stressing that 'This is not terrorism, this is a rebellion for honourable peace.'

The rallies reveal that the BDP's election campaign for the June 2011 elections focused mainly on 'regionalization' and called for a new model where elected regional councils would assume responsibility in fields such as education, health, social services, culture and others. ${ }^{36}$ One major cross-cutting point in all rallies regardless of the speaker was the focus on an inward-looking version of Kurdish nationalism. This meant that both speeches that were marked by a religious tone and those that focused on specific demands such as self-determination and the call for a political status for the Kurds were based on the needs and grievances of the Kurds. Thus, for the 2011 elections, the BDP's discourse remained strictly confined to the Kurdish issue, with limited appeal to the wider electorate. ${ }^{37}$

\section{AKP election rally speeches in the June 2015 elections}

The AKP rallies for the June 2015 elections were marked by great continuity with the 2011 election rallies. Both the tone of the rallies and the themes were highly similar, despite the change in leadership from Recep Tayyip Erdoğan to Ahmet Davutoğlu after the former became president in August 2014. For the June 2015 elections, the Bingöl, Diyarbakır, Kars and Mersin election rallies were selected for analysis. Like the 2011 period, these rallies were centred on the themes of religious fraternity. This revealed continuity in terms of the AKP's effort to promote a synthesis of Islamic identity and fraternity between Turks and Kurds. In continuity with the previous period, the speeches engaged in negative campaigning against the HDP and the CHP on the grounds that both parties tried to suppress and even humiliate religion at different periods. Davutoğlu's accusations of the HDP for a statement that 'the Islamic veil is humiliating for women' (Diyarbakır rally) and of HDP's 
cooperation with Israel were major indicators of this approach. Accusations of HDP and CHP applying similar forms of oppression towards the Kurds and devoted Muslims in Turkey in general were also repeated.

In the Bingöl rally of 7 May 2015, a religious tone was applied with accusations towards HDP regarding Jerusalem and HDP's stance towards Israel. ${ }^{38}$ In addition, Davutoğlu made the accusation that the HDP was collaborating with the CHP and the 'parallel structure' referring to the Gülen Movement. Davutoğlu gave the message that voting in the elections would be made between voting for peace or voting for violence and discrimination. Following the same pattern, Davutoğlu in the Van rally of 31 May 2015 stated the common aspects of the HDP and the CHP, that both parties were 'foreign to people's needs and demands' and that they are both 'oppressive and in favour of uniformities, i.e. not supporting pluralities in the society'. ${ }^{39}$ Both CHP and HDP 'serve ideologies, they do not serve the people'. In the Diyarbakır rally, Davutoğlu accused the HDP for suggesting the Kurdish call to prayer and created parallels to the CHP's decision in the 1940s for the Turkish call to prayer. However, Davutoğlu balanced his criticism by making reference to an Islamic ceremony (mevlid) he listened to in Kurdish and enjoyed. He also accused the HDP for a statement that the Islamic veil is humiliating women. Davutoğlu created parallels between the CHP and the HDP by stating that as the CHP promoted Turkish nationalism, the HDP promoted Kurdish nationalism.

Second, there was emphasis on historic personalities and religious fraternity between Turks and Kurds emanating from the common past. For example, the Hakkâri rally on 27 May $2015^{40}$ was combined with the opening ceremony of the Selahaddin Eyyubi (Saladin) airport in Hakkâri. In his speech, Davutoğlu, continuing his conservative tone, explained the decision to name the airport after Selahaddin Eyyubi was taken because he symbolized unity among Muslims. This was also a response to accusations against the HDP on the statement that Jerusalem is the sacred land of the Jews. Similarly, Davutoğlu's Diyarbakır rally on 31 May 2015 was centred on two main themes, religion and fraternity emanating from a common past. ${ }^{41}$ The conservative tone is discerned through references to the Al-Aqsa mosque, to Selahaddin Eyyubi, to the Great Mosque of Diyarbakır and declaring Diyarbakır as the 'sister city' of Jerusalem.

Similar to the previous period, in all four rallies the Kurdish issue was approached in terms of the legal steps taken to ease the grievances that the Kurds had faced for decades. These steps include the abolition of the state of emergency, and lifting of bans on the Kurdish language. Davutoğlu listed these steps as the abolition of the state of emergency, the abolition of the State Security Courts, the reforms related to the bans on the Kurdish language and the initiation of broadcasting in Kurdish.

\section{HDP election rally speeches in the June 2015 elections}

For the June 2015 elections, the Bingöl, Mersin, Muş and Van election rallies were selected for analysis. HDP's 5 June 2015 Diyarbakır election rally was cancelled due to a terrorist attack in the rally area. The Diyarbakır bomb attack was only one of a total of 123 violent attacks on the electoral activities by the HDP. ${ }^{42}$

The June 2015 rally speeches were conducted by the co-chairs of the HDP, Figen Yüksekdağ and Selahattin Demirtaș. While all rallies centred on common themes of democratic rights, a difference in tone was discerned between the more moderate speeches by 
Selahattin Demirtaş and the more radical-leaning speeches by Figen Yüksekdağ. The most significant change compared to the previous period is the move from territorial claims to rhetoric on rights and inclusivity, which paralleled the election manifesto. The speeches reveal HDP's emphasis on a 'Türkiyeli' identity with the aim of expanding the party appeal beyond ethnic Kurds. This was combined with a leftist agenda that aimed to address the grievances of all the oppressed societal groups in Turkey.

The focus on rights and inclusivity could be explained on two grounds: first, the HDP's own transformation in moving beyond pro-Kurdish claims to a wider rhetoric on inclusivity of all the excluded and the oppressed in society, including the rights of minorities that were not officially recognized as such and the rights of the marginalized such as the LGBTI (Lesbian, Gay, Bisexual, Transgender, Intersex). Second, human rights and inclusivity were also two major demands of the HDP with regards to the peace process. The pro-Kurdish political actors approached the Kurdish issue as a problem of lack of democracy and the need for providing cultural rights for Kurds along with the recognition of Kurdish identity and a political status to Kurds. Selahattin Demirtaş's Bingöl election rally speech of 9 May 2015 was centred on concerns with the economy and more specifically on the need for creating change in the conditions of the poor and especially the workers and the farmers. ${ }^{43}$ With regards to the resolution process, Demirtaş underlined that the HDP would stick with the resolution process and the Dolmabahçe Agreement. ${ }^{44}$ References to religion were made in the framework of freedom of conscience and the need to embrace each faith. Demirtaş also underlined that in Kobane, Islam was defended by the Kurds. ${ }^{45}$ Similarly, Demirtaş's speech in the Mersin rally on 18 May $2015^{46}$ was based on a call for nondiscrimination of any identity and for non-aggression despite provocations directed towards the party. Poverty was again a main theme, and Demirtaş accused the AKP of corruption and the mismanagement of resources for personal gain.

The HDP co-chair Figen Yüksekdağ employed a more radical tone in HDP rallies. Figen Yüksekdağ's Muş election rally speech on 11 May 2015 centred on accusations towards the AKP that it had enforced conflict rather than peace politics since the initiation of the resolution process. Yüksekdağ noted that:

During the resolution process while our leader Öcalan showed prudence for the continuation of the process, the government built police stations, killed our children, and lived on deaths and war. We did not initiate the peace process for the sake of Erdogan. Our collocutor in this process is our honoured people, the workers, the laborers, the oppressed. ${ }^{47}$

Yüksekdağ's comments on religion were based on criticism of the AKP and Erdoğan:

They defend the Diyanet ${ }^{48}$ because it is an institution of their creation, they are not defending our sacred values [...] they propagate with the Kurdish Koran.

She also referred to the lack of accountability in the case of the head of the 1980 military coup Kenan Evren and called for accountability in the Uludere (Roboski) incident where 34 young Kurdish civilians were killed following an attack of the Turkish air force. Following this radical discourse, Yüksekdağ's Kars election rally of 22 May 2015 was similarly centred on the argument that the resolution process was initiated and owned by Öcalan and that the continuation of the process was linked to HDP's prudent and consistent behaviour. ${ }^{49}$ Yüksekdağ accused the AKP of relying on conflict and war with reference to the 
AKP's stance during the Kobane incident. ${ }^{50}$ She was also critical of the presidential system that Erdoğan had endorsed.

\section{Conclusion: the enduring appeal of religion and victimhood}

The analysis of the June 2011 and June 2015 rally speeches reveals interesting results with regards to the approach of the two parties to the Kurdish issue. The AKP shifted from its support for a 'Türkiyeli' identity that was a key element of the party's political programme in the mid-2000s, bypassed ethnicity and moved to an increasingly pro-Islamic discourse projecting Sunni Islam as an insoluble bond between Turks and Kurds, keeping a uniform line in both election campaigns. On the other hand, the HDP radically changed its rhetoric between the two elections from an ethnic Kurdish nationalist to a 'Türkiyeli'-driven one, meaning that it welcomed a Turkey with ethnic, religious and cultural diversity, without prioritizing Sunni Islam. These findings suggest the need to reconsider the two parties' positions within the more general transformation process since 2002.

The election speeches by Erdoğan and Davutoğlu in 2011 and 2015, respectively, reveal the AKP's emphasis on the notions of religion-based fraternity as binding tools for Turks and Kurds. This is closely related to the way the AKP has projected itself as a conservative party that challenged Kemalist secularism. Regarding the Kurdish issue, this enabled the AKP to promote its discourse on religious fraternity by differentiating itself from the Kemalist state tradition which it accused for the previous policies of assimilation and denial towards the Kurds. The discourse on religious fraternity was combined with an 'attack' strategy towards the Kurdish movement for being anti-Islamic and therefore unfit to represent the Kurdish electorate. In that view, conservative Turks and Kurds were both victims of the Kemalist state elite that attempted to uproot Islam and belittle its believers. Yet this struggle failed, and the AKP was empowering dispossessed Turks and Kurds. The proKurdish political parties with their left-wing and secularist underpinnings were portrayed as alien to the pious Kurds, if not agents of foreign, anti-Islamic forces.

At the same time, the AKP's references to religious fraternity can be seen as a departure from the civic, religion and ethnicity-free 'Türkiyeli' model, to that of the 'Muslim Turk' and a reversal to the mainstream - since the 1980s - discourse of the Turkish Islamic synthesis. Turks and Kurds were depicted as 'brethren in Islam', thereby confirming both the power of the 'TIS' model and the limits of the ability of the AKP to recast and eventually solve the Kurdish question.

The HDP, on the other hand, moved in the opposite direction. While before 2015 it had generally focused on courting the vote of ethnic Kurds by adopting a programme addressing only the grievances of the Kurdish population, in the June 2015 election campaign it rebranded itself. By declaring itself a 'party of Turkey' (Türkiye partisi), it aimed to distance itself from its monothematic legacy. This marked a move from an introvert Kurdish nationalism to a more liberal and extrovert Türkiyelilik agenda. In the election speeches for the June 2015 elections, extensive references to 'rights for all' and the left-leaning statements on restructuring the economy and protecting the rights of the dispossessed were prominent themes. While the 2011 speeches remained disorganized and highly contingent on the personalities of the independent candidates of the BDP/EDÖB, the speeches for the June 2015 elections revealed an effort to project rights for all marginalized and oppressed groups as a common theme and to move beyond territorial focus. By 
appointing conservative candidates and highlighting the contradictions of the AKP policy regarding Sunni Islam, the HDP improved its Sunni Islamic credentials and was also able to win a considerable part of the Kurdish conservative vote.

While the AKP was shifting from citizenship to religion and the HDP shifting from ethnicity to citizenship to address the Kurdish question, victimhood remained an enduring theme in their political communication. The AKP's victimhood claim remained focused on the secularist-conservative divide of Turkish society, which cut through the Kurds as well, while the HDP victimhood claim expanded. It reached beyond the limits of the oppressed Kurdish minority to all citizens oppressed by the Turkish state. This referred not only to the Kurdish minority, but also to all the various groups that have faced oppression by the Turkish state. Victimhood was not defined in religious or ethnic but in citizenship terms. This shift proved to be one of the key reasons for the electoral success of the HDP in the June 2015 parliamentary elections. Winning votes from conservative Kurdish, secular and liberal Turks and minority groups, the party received 13.16 per cent of the vote, the highest in the history of pro-Kurdish parties and gained 80 seats in the parliament. Emphasis on citizenship while not ignoring reference to two crucial symbolic resources of Turkish political party mobilization, religion and victimhood, proved a very successful election strategy.

\section{Disclosure statement}

No potential conflict of interest was reported by the authors.

\section{Funding}

This work is supported by Education, Audiovisual and Culture Executive Agency [grant number 586489-EPP-1-2017-1-TR-EPPJMO-CHAIR].

\section{ORCID}

loannis N. Grigoriadis http://orcid.org/0000-0003-0882-6125

Esra Dilek http://orcid.org/0000-0002-6157-0504

\section{Notes}

1. Alevi Kurds comprise an exception to that rule.

2. There is a caveat on this: Turkey's sharply reduced in size non-Muslim minorities were neither accepted as equal citizens nor were they given the chance to assimilate to the Turkish nation.

3. Introduced by a group of conservative intellectuals in the 'Hearth of Enlightened' (Aydınlar Ocă̆ı), the Turkish-Islamic Synthesis restored Sunni Islam as an essential element of Turkishness.

4. Article 24 of the 1982 Constitution made religious education courses mandatory, while construction of mosques throughout the country skyrocketed and graduates of religious vocational schools (imam-hatip) were allowed to sit for university exams.

5. M. Yegen, The Kurdish Question in Turkey: Denial to Recognition in M. Casier and J. Jongerden (eds.), Nationalisms and Politics in Turkey: Political Islam, Kemalism, and the Kurdish Issue (London: Routledge, 2010). 
6. B. Duran, The Justice and Development Party's 'New Politics': Steering toward Conservative Democracy, a Revised Islamic Agenda or Management of New Crises?' in U. Cizre (ed.), Secular and Islamic Politics in Turkey: The Making of the Justice and Development Party (Oxon: Routledge, 2008), p.82.

7. I. N. Grigoriadis, 'Islam and Democratization in Turkey: Secularism and Trust in a Divided Society', Democratization Vol.16, No.6 (2009), p.1199.

8. Newsdesk, 'Kürt Sorunu Benim Sorunum [The Kurdish Problem Is My Problem]', BBC Turkish, 12 August 2005.

9. I. N. Grigoriadis, 'Turk or Turkiyeli? The Reform of Turkey's Minority Legislation and the Rediscovery of Ottomanism', Middle Eastern Studies Vol.43, No.3 (2007), p.430.

10. Newsdesk, 'Türkiyelilik Bilincini Geliştirmeliyiz [We Need to Nurture "Turkiyelilik" Consciousness]', Hürriyet, 2 September 2003.

11. Ö. Tezel and S. Güleç, 'Erdoğan Konuştu Kimlik Altüst Oldu [Erdogan's Speech 'Upset' Identity]', Sabah, 22 August 2005.

12. Newsdesk, 'Erdoğan Bir Kez Daha "Üst Kimlik" Dedi [Erdoğan Talked Once More About "Supra Identity"] ', CNN Turk, 17 March 2009. Erdogan again made references to Türkiyelilik at his victory speech after winning the presidential elections in August 2014. Newsdesk, 'Erdoğan'ın Balkon Konusmasında Iki Önemli Vurgu [Two Important Highlights from Erdoğan's Balcony Speech]', Haberler, 11 August 2014, declaring his intention of promoting cohesion after a polarized election campaigning period.

13. Y. Taskin, 'AKP's Move to "Conquer" the Center-Right: Its Prospects and Possible Impacts on the Democratization Process', Turkish Studies Vol.9, No.1 (2008), p.62.

14. C. Çiçek, 'The Pro-Islamic Challenge for the Kurdish Movement', Dialectical Anthropology, Vol.37 (2013), p.160.

15. Newsdesk, 'Tarık Ziya Ekinci: "Kardeşlik Söylemi Köleleștirici; Kürtler Kardeş Olmak Değil, Eşit Haklı Vatandaşlık İstiyor!" [Tarik Ziya Ekinci: "The Discourse on Fraternity Is Servitudinal; the Kurds Want Equal Citizenship, Not Fraternity!"]', T24, 17 September 2015.

16. Z. Yilmaz, 'The AKP and the Spirit of the "New" Turkey: Imagined Victim, Reactionary Mood, and Resentful Sovereign', Turkish Studies Vol.18 (2017), pp.6-10.

17. The BDP replaced the banned DTP. It was itself succeeded by the HDP in 2014.

18. Newsdesk, 'Erdoğan: Ben Bu Milletin Başkanıyım, Pkk Silah Bırakmadan Bu Sürece Daha Fazla Devam Edemeyiz [Erdoğan: I Am the President of This Nation, We Cannot Continue the Process Unless the PKK Is Disarmed]', T24, 23 March 2015.

19. E. Yazdiç-Demir, 'HDP: Cözüm Sürecinin Yeniden Başlatılması ıçin Önerilerimiz Var [HDP: We Have Proposals for Resuming the Resolution Process]', HaberTurk, 6 December 2015.

20. Newsdesk, 'Erdoğan: "Dolmabahçe Mutabakatı" Ifadesini Cımbızlarım [Erdoğan: I Strongly Condemn the Expression "Dolmabahçe Agreement"]', BBC Türkçe, 17 July 2015.

21. Other means of election campaigning include paid campaigns through conventional print media, the internet and social media, and the work of local party offices.

22. Except for HDP's Mersin (Mediterranean region) rally for the June 2015 elections. For this election period, the Diyarbakır rally of the HDP was cancelled on 5 May 2015 due to a bomb attack to the rally area. After careful examination, the Mersin rally was selected on the basis that Mer$\sin$ is a city with a large Kurdish migrant population and is a major election district for both the AKP and the HDP.

23. G. M. Tezcur, 'Trends and Characteristics of the Turkish Party System in Light of the 2011 Elections', Turkish Studies Vol.13, No.2 (2012), p.126.

24. A thorough discourse analysis of all rally speeches during the election campaigns lies beyond the scope of this paper.

25. N. S. Satana, 'The Kurdish Issue in June 2011 Elections: Continuity or Change in Turkey's Democratization?', Turkish Studies Vol.13, No.2 (2012), p.177.

26. The Diyarbakır rally speech is retrieved from the AKP official website. Available at http://www. akparti.org.tr/site/haberler/1-haziran-diyarbakir-mitingi-konusmasinin-tam-metni/8230\#1 (last accessed 30 September 2016). 
27. The Bingöl rally speech is retrieved from the AKP official website. Available at http://www. akparti.org.tr/site/haberler/8-haziran-bingol-mitingi-konusmasinin-tam-metni/8406\#1 (last accessed 30 September 2016).

28. The Van rally speech is retrieved from the AKP official website. Available at http://www.akparti. org.tr/site/haberler/20-mayis-van-mitingi-konusmasinin-tam-metni/7886\#1 (last accessed 30 September 2016).

29. The speech for the Hakkâri rally is retrieved from the AKP official website. Available at http:// www.akparti.org.tr/site/haberler/21-mayis-Hakkâri-mitingi-konusmasinin-tam-metni/7892\#1 (last accessed 30 September 2016).

30. The Bingöl election rally speech by Altan Tan was retrieved from the YouTube video clip of the rally published by the BDP. Available at https://www.youtube.com/watch?v=el-MkYLQPzo (last accessed 30 September 2016).

31. Newsdesk, 'BDP Destekli Bağımsızlar Mitingi [Meeting by Independent Candidates Supported by the BDP]', Hürriyet, 4 June 2011.

32. The analysis of this rally speech was mainly based on news articles and especially Milliyet newspaper's report that provided extensive excerpts from the candidate speeches. Available at http://www.milliyet.com.tr/bdp-den-diyarbakir-da-govde-gosterisi/siyaset/siyasetdetay/ 04.06.2011/1398553/default.htm (last accessed 30 September 2016).

33. C. Emir and S. Sunar, 'BDP'den Diyarbakır';da Gövde Gösterisi [BDP's Show of Strength in Diyarbakır]', Milliyet, 4 June 2011.

34. The Kars election rally speech by Osman Baydemir was retrieved from the YouTube video clip of the rally published by the BDP. Available at https://www.youtube.com/watch?v=e2DOMjzSxAM (last accessed 30 September 2016).

35. A video record of the Hakkâri rally is not available. Information on the rally speeches by candidates is retrieved from news sources. See Ö. Çiriş, 'Demirtaş'tan Seçime Katılmama Şartı [Demirtaş Reveals Condition to Not Participate to Elections]', Milliyet, 6 June 2011; Newsdesk, 'Historic Meeting in Hakkari [Hakkari'de Tarihi Miting]', Evrensel, 7 June 2015.

36. F. Baskan and A. Güney, 'Election Report and Analysis: Turkey's June 2011 Parliamentary Elections', Journal of Balkan and Near Eastern Studies Vol.14, No.1 (2012), p.169.

37. S. Aydin-Duzgit, 'No Crisis, No Change: The Third AKP Victory in the June 2011 Parliamentary Elections in Turkey', South European Society and Politics Vol.17, No.2 (2012), p.336.

38. Ahmet Davutoglu's Bingöl rally speech was retrieved from the YouTube video clip of the rally. Available at https://www.youtube.com/watch?v=8b8ImhZa5G8 (last accessed 1 October 2016).

39. Ahmet Davutoglu's Van election rally speech is retrieved from YouTube video clip uploaded by the AKP. Available at https://www.youtube.com/watch?v=ldc3u4uy34I (last accessed 1 October 2016).

40. Ahmet Davutoglu's Hakkâri rally speech was retrieved from YouTube video clip of the rally. Available at https://www.youtube.com/watch?v=gEl82_dg_1E (last accessed 1 October 2016).

41. Ahmet Davutoglu's Diyarbakır rally is retrieved from AKP official website. Available at http:// www.akparti.org.tr/site/haberler/diyarbakir-bize-ilahi-kardesligi-anlatir/75494\#1 (last accessed 1 October 2016).

42. O. Kemahlioglu, 'Winds of Change? The June 2015 Parliamentary Election in Turkey', South European Society and Politics Vol.20, No.4 (2015), p.453.

43. Selahattin Demirtaș's Bingöl election rally speech is retrieved from YouTube video clip of the rally. Available at https://www.youtube.com/watch?v=FnY_-awcqcQ (last accessed 1 October 2016).

44. The 'Dolmabahçe Agreement' was a document outlining a ten-item list of priorities for the resolution of the Kurdish issue, which was allegedly agreed upon by the two parties.

45. In Kobane, a Syrian town next to the Turkish border, Kurds from Syria and Turkey successfully repelled in late 2014 an attack of the Daesh troops, thanks to the support of the international community and despite Turkey's initial acquiescence to the occupation of the town by Daesh.

46. Selahattin Demirtaş's Mersin election rally speech is retrieved from YouTube video clip of the rally. Available at https://www.youtube.com/watch?v=7JymoZwJLj0 (last accessed 1 October 2016). 
47. Figen Yüksekdağ's Muş election rally speech is retrieved from the YouTube video clip of the rally. Available at https://www.youtube.com/watch?v=mFKkcd6Kn2l (last accessed 1 October 2016).

48. The term 'Diyanet' refers to the Directorate of Religious Affairs (Diyanet işsleri Başkanlığı), the state institution administering Sunni Islamic affairs in Turkey.

49. Figen Yüksekdağ's Kars election rally speech is retrieved from YouTube video clip of the rally. Available at https://www.youtube.com/watch?v=vkhEaGa7Tb0 (last accessed 1 October 2016).

50. The apparent acquiescence of the AKP government to Daesh's imminent conquest of Kobane threatening thousands of Syrian Kurdish civilians dismayed many conservative AKP voters of Kurdish descent and became a crucial argument in the HDP's efforts to undermine the religious fraternity argument of the AKP vis-à-vis the Kurds.

51. G. Yilmaz, 'Exploring the Implementation of Minority Protection Rules in the "Worlds of Compliance": The Case of Turkey', Perspectives on European Politics and Society Vol.13, No.4 (2012), p.418. 